\title{
THE SIGNIFICANCE OF ISLAMIC VALUES AS THE PRINCIPLES \\ OF LIFE IN A MODERN WORLD
}

By: Muhammad Qorib

\section{The Writer is Lecturer at Muhammadiyah University of North Sumatera}

Currently we are dealing and living in the great currents of globalization. The process of change takes place so quickly. According to Paul Streeten in his book, "Globalisation: Threat and Opportunity (2001)", besides convenience globalization also gives variety of social changes. Streeten said that globalization gives birth to threat on the one side and the opportunity on the other side. ${ }^{1}$ Sociologically, threat and opportunity of course will also be faced by every religion as an important element of society. Therefore, inevitably, the roles of religion need to be revitalized. People still expect that religion can face various problems arising as a consequence of the changes. Komaruddin Hidayat even states that religion as a figure personifying the "superman" who is able to make a miracle to find a way out on a variety of issues that arise in the community. ${ }^{2}$ This paper will see how religion promotes the basic values to face the modern life. This paper uses a hermeneutic approach to the Quran and hadith as the basic values.

\section{Learning from Past Experience}

The process of change by negating the role of religion at least can be seen from the experience of the West in the past. Why is the West? Some experts said that the West is the oldest model for the life of the project of modernism, the people live in thouroughly modernized society. ${ }^{3}$ The western experience can give a real example of the construction without religion. If we trace the modern age in the West which began in the seventeenth century, it was started by the supremacy of rationalism, empiricism and positivism. This fact can be understood, because

\footnotetext{
1 See Paul Streeten, Globalisation: Threat and Opportunity (Michigan: Copenhagen Business School Press 2001). 36.

${ }^{2}$ Komaruddin Hidayat, Wahyu di Langit Wahyu di Bumi (Jakarta: Paramadina, 2003), p.

${ }^{3}$ Loek Halman and Ole Riis, ed., Religion in Secularising Society: The Europen Religion at the End of the 20th Century (Leiden: Brill, 2003), p. 1
} 
the modern century is built on the basis of the separation between science and philosophy from the influence of religion. A relation between rationalism and empiricism in one epistemology package by Thomas Henry Huxley is called the scientific method. ${ }^{4}$

The discovery of the scientific method and rational empirical character miraculously bring the progress of science and technology. Industry and a wide variety of scientific discovery bring easiness of life, open new horizons of life, and give birth to a new life pattern called modernism. Modernism is characterized by rationalism, progress, and secularism. Thus, the Western modern age is an age when man finds himself as a force that can resolve the problems of life. Human beings are seen as great creatures. They are independent from God and nature. Western modern humans intentionally break away from their attachment to the Lord. They build the human order according to the human center. Human beings become masters of their own destiny, which send to the dissolution of spiritual values. As a result, the modern man in the end was unable to answer the problems of life himself. ${ }^{5}$

It looks interesting if we feel the anxiety of E.F. Schumacher towards modernization in the West. He explained that the various crises in the West either environment, economics, politics, dwindling supplies of food and so on stem from the disappearance of religious consciousness within Western societies. They dumped a fundamental requirement which is an important pillar of human life. Shumacher confirms that the recovery of the condition of the West who are suffering from the disease is the return to religion. The dominance of science and technology need to be balanced with something that is perennial. ${ }^{6}$ If it is explored further, the man in English is called human being. The second syllable contains a special meaning and can not be separated. Human refers to the realm of human

${ }^{4}$ See David E. Alexander and Rhodes W. Fairbridge, ed., "Thomas Henry Huxley (18251895)", in Encyclopedia of Environmental Sciences (Doordreecht: Kluwer Academic Publishers, 1999), pp. 331-332.

See Ali Maksum, "Spiritualitas Abad Modern: Reposisi Islam dalam Kancah Kebangkitan Agama", (quoted from: http.www.arsip.masjid.telkom.co.id [home page on-line]: Internet (April 14, 2013 time 17.53 Indonesian Time). See also the complete explanation in Seyyed Hossein Nasr, Islam and The Plight of Modern Man (Virginia: ABC International Group, 2000).

${ }^{6}$ See E.F. Schumacher, A Guide for the Perplexed (Random House, 2011). 
flesh as body and mind, while being refers to the realm of the soul. Human and being are the two entities that can not be separated. The separation between them of course would bear negative consequences for the man himself.

Modern civilization that developed in the West since the days of the renaissance is an experiment that has failed so badly, so the human being steps into doubt whether they can find other ways in the future. It is as stated by Seyyed Hossein Nasr that the modern man who rebelled against God, has created a science that is not based on religion but on the strength of the light of human reason alone to get data through the senses. Modern civilization is only enforced on the foundation of the concept of man that does not include the most essential aspect of the man himself. As a result of the above phenomena, Western society, which is often classified as the post-industrial society, a society that has reached the level of material prosperity with technological devices that completely mechanically and automatically, increasingly feel a sense of anxiety. The situation is precisely due to the luxuries of life that are already achieved. They have become devotees of science and technology. Unwittingly, integrity and humanity are trapped in the rationality of the technological network system that is not humane. $^{7}$

West bitter experience at least gives some reflections to us: First, a process of change taking place in society by negating religion does not make the society more advanced but it puts the society into regress. The criterion of the progress of society when clothing, food and shelter, and most importantly spiritual are fulfilled. Second, the process of change that negates religion is substantively against human entity as physical and psychological being. Third, religion will give moral reference to the direction in which the process of societal change lasts. Fourth, religion can provide theological motivation to every subject of development. Thus, the process of change is not only the need of the world, but also an integral part of the divine value.

\footnotetext{
${ }^{7}$ Ali Maksum, "Spiritualitas Abad Modern".
} 


\section{Back to Religion}

The expectations of religion as a sacred institution that can overcome social sickness can actually be seen from the predictions of futurologist John Nasbitt and Patricia Aburdene. In the modern era, religion is usually eroded by the the rapid development plus individualistic and materialistic life style. But according to Naisbitt and Aburdene, religion gets important moment of resurrection. Both explained that modern society is too tired of the physical problems, so they need something that can lead them and simultaneously release the thirst of life through the spiritual path (religion). Here, religion plays a role. Departing from American case, Naisbitt and Aburdene explained that in the sophisticated countries, people search for the religious and spiritual movements. It becomes something quite problematic and difficult to be accepted if spirituality is only a spiritual movement without formal religion as it has existed. The term that is used by Naisbitt and Aburdene is "spirituality yes" and "organized religion no". What else in Islam, spirituality and religion are two things that are inherent, both are inseparable. ${ }^{8}$ Nevertheless, the era of religious revivalism appears to be so obvious.

Therefore, an argument that can not be negotiable if religion can give moral guard. When it is examined comprehensively, Islam is a religion whose all aspects surround the issues of life, ranging from theology, morality, worshipping, and social relation. M. Quraish Shihab states that it is called kaaffah (comphrehensiveness). ${ }^{9}$ Islam means submission himself/ herself totally to God, but it does not mean a religion which only includes dogma or set of certain rites. According to the wide meaning, Islam is a doctrine, a world view, a culture and a civilization which is based on monotheism. In the perspective of the Quran, Islam is religion for all (rahmatan lil 'alamiin) (Q.V. Al-Anbiyaa'/ 21: 107). Islam is not a religion that only invites his people to happiness in the final day, but also

${ }^{8}$ See John Naisbitt and Patricia Aburdene, Megatrends 2000: New Directions for Tomorrow (London: Siddwick \& Jackson, 1990).

${ }^{9}$ See M. Quraish Shihab, Wawasan Al-Qur'an: Tafsir Maudhu'i atas Berbagai Persoalan Umat (Bandung: Mizan, 1996); Tafsir Al-Misbah: Pesan, Kesan dan Keserasian Al-Qur'an, Vol. 1 (Jakarta: Lentera Hati, 2006). 
encourages the people to achieve the life in this world. In Islam, the realm of the world and the hereafter is an inseparable entity (Q.V. Al-Baqarah / 2: 201). ${ }^{10}$

Islam explains that human being has two positions: 'abd and khaliifah. As ' $a b d$, he should become an active slave in front of God. As khaliifah, it is a substitute for responsibility, inviting to do goodness (ma'ruuf) and forbidding badness (nahyu 'an al-munkar). He is also prohibited from making mischief on earth. As a khaliifah, human being must be qualified. Therefore, every khaliifah must learn throughout life anywhere and anytime. Islam gives a very high appreciation for the khaliifah. Khaliifah is highly knowledgeable and at the same time firmly believes in God. The such khaliifah is called uluul al baab ${ }^{11}$ (Q.V. Ali- 'Imraan / 190-191). There are four main characteristics of khaliifah as mentioned in the verse, namely: First, he who always does $d z i k r$ (remembrance of God, calls the names of God, and reflects favors given by God). Second, he who does reflection or analysis. Third, he who is fully aware of the wisdom behind a variety of God's creation. Fourth, he who always recognizes all the greatness of God and exspresses the human weakness. ${ }^{12}$

In the life of the nation, Islam gives moral principles. We can trace them in the Quran and Sunnah. The moral principles are also listed in the Charter of Medina (Arabic: Miitsaaqul Madiinah). This charter contains a social consensus among Muslims, Jews, Christians and polytheists of Medina to realize social welfare regardless of their different backgrounds. William Muir, as quoted by Nouruzzaman Siddiqi, stated that the Medina Charter as the earliest charter known and practiced by mankind. ${ }^{13}$ Some important things that can be observed in the Medina Charter are as follows:

First, the unity of mankind despite coming from different backgrounds. Second, the freedom of religion and to perform worshipping according to their beliefs. It is also stated in the Holy Quran, "for you your religion and to me mine

10 See Nouruzzaman Shiddiqi, Jeram-Jeram Peradaban Islam (Yogyakarta: Pustaka Pelajar, 1996), p. 290.

${ }^{11}$ Nouruzzaman Shiddiqi, Jeram-Jeram, p. 291.

${ }^{12}$ M. Quraish Shihab, Tafsir Al-Misbah, Vol. 2, pp. 308-312.

${ }^{13}$ Nouruzzaman Shiddiqi, Jeram-Jeram, p. 291. 
and not allowed to harass other religions" (Q.V. Al-Kaafirun/ 109: 6). Third, a sense of togetherness. In Islam all members of society have the same rights and obligations. Society is described as a set of parts of the body which is equally in many aspects. The Community should help each other in the spirit of high solidarity. The weak have to be defended and the poor should be helped. Under whatever circumstances however, one should not be treated poorly. One is prohibited to keep jealousy heart. The rich must be aware that the property is a gift of God and can be compiled by the help of others. Therefore, he must always be aware that the assets can be shared with others, especially the poor and the needy. Individual property rights are recognized as well as the rights of every person should be respected. Fourth, the enforcement of justice. All persons are equal before the law. Nobody has privilege in law. For the sake of justice and the maintenance of public order and peace, the law must be upheld. Therefore, it is forbidden to protect the perpetrators whoever they are. Fifth, peace. Peace is the primary goal. War should not be continued if the opponent request peace. But the seeking of peace must not sacrifice justice and truth. Sixth, deliberation. All issues of common interest should be settled amicably which is based on freedom of speech. Decisions are taken based on the truth.

More explicitly, the Islamic values in the process of changing society take an unlimited space. The principles that are promoted by Islam can traverse space and time eventhough they need re-assessment and understanding. This allows the values in line with the changes. In guarding the process of changing society, Islam lays the basic principles. Here, I take two principles that are considered as the most important principles. They are economic principle and politic principle. Several other principles are also in fact no less important, but because of the focus some other principles are not discussed.

Firstly, the economic principle. In Islam, seeking sustenance is an integral part of the chain of worshipping God. Islam dismisses the notion of most people that this religion gives such a great rejection of the economic sphere. Precisely, true Islam strongly advises it. The economic sphere needs ethics in order to save humanity and to keep other people's life. Humans are commanded by God to seek 
sustenance not only for themselves, but the Quran also orders to find what is called fadl Allaah, literally means "the advantages that come from God". One verse that describes this can be seen in the following: "When you have finished the prayer then go out on earth and look fadl Allaah ...." (Q.V. Al-Jumu'ah / 62: 9). This verse means that the rich can help the poor positively. They must distribute their belongings to those who are weak economically. The verse also firmly explains that the property that is owned by someone can be used to save other people's rights. That must be fulfilled if the continual reward from God becomes the basic goal. ${ }^{14}$

Islam also explains that the balance in economics is absolutely necessary. The balance will lead to the prevention of all forms of monopoly and concentration of economic power under the one hand or one group. In other words, Islam rejects firmly the form of capitalism. In this case, Quran criticizes firmly the limited recycling of economics which makes wealth only around certain people or certain groups, "Do not only circulate things on the rich among you ...." (Q.V. Al-Hashr / 59 : 7). From here, we also know that Islam gives the strong ban on landfilling and waste goods. It can be observed in Q.V. Al-Tawbah / 9: 34 that Islam gives such a harsh threat to the stockpiling of goods. Prophet Muhammad also confirmed in a hadith: "Who hoards food for forty days, with the objective of raising prices, so he is innocent to Allah and Allah also disassociates himself from Him." Some pundits make the verse and the hadith as an argument granting the authority to revoke the property of speculative hoarding, smuggling, and taking advantage excessively, since speculative hoarding causes the price to increase. ${ }^{15}$

Islam also forbids usury behavior. The word usury in terms of language means "excess". If we just stop at the literal meaning of this, then the logic statement about usury that was expressed by the opponents at the time of the Prophet can be justified. When they say that buying and selling is tantamount to riba (Q.V. Al-Baqarah / 2: 275). God answered them emphatically, that God justifies the buying and selling and forbids usury. In the Qur'an, the word usury is

\footnotetext{
${ }^{14}$ M. Quraish Shihab, Wawasan Al-Quran, p. 403.

${ }^{15}$ M. Quraish Shihab, Wawasan Al-Quran, pp. 411-412.
} 
repeated eight times. Efforts to understand what is meant by usury is by studying verses in Medina, or more specifically the key words in these verses are: adh'aafan mudhaa'afah (double). Scholars like Muhammad Rashid Rida understood that usury is forbidden. Double folding here means the "multiplication from time to time without stopping". ${ }^{16}$

Secondly, the principles in politics. In modern Arabic dictionary, the word is usually translated with the word siyaasah. The word is derived from a root word sasa-yasusu commonly defined as driving, controlling, regulating, and so forth. Eventhough we will not find the word siyaasah in the Quran, but it does not mean that the Quran does not elaborate on political issues. Many ulama (religious leaders) write papers in the fields of politics with reference to the Qur'an and Sunnah. Even Ibn Taymiyyah (1263-1328) named one of his scientific writings with Al-Siyasah al-Syar'iyyah (Religious Politics). The description of Quran about politics at a glance can be found in the verses that have the word root hukm. This word originally means "blocking" or "prohibit in order to improve". It appears from the word which originally means wisdom of control. This meaning is in line with the original meaning of sasa-yasusu-sais-siyasat, which means "driving, controlling and controlling measures". ${ }^{17}$

Political power is given by God to man. This is done through the conferment of the engagement. This bond is established between the ruler with God on the one side and the public on the other side. The agreement with God in the Quran called 'ahd. There is also an agreement with the public that is called the pledge of allegiance. The agreement refers to the mandate and should be implemented. From here it can be concluded that if the command of obedience to the ruler (uli al-amr) is preceded by an order to fulfill the mandate (Q.V. Al-Nisa'/ 4: 58-59). Surah Al-Nisa verses 58-59 are assessed by scholars as the main principles that bring together Islamic teachings about power and government. Rashid Rida argued that even if there were no other verses that speak about the government, then this clause has been adequate. While the mandate is associated

\footnotetext{
${ }^{16}$ M. Quraish Shihab, Wawasan Al-Quran, pp. 413-414.

${ }^{17}$ M. Quraish Shihab, Wawasan Al-Quran, pp. 416-417.
} 
with many things, one of which is fair treatment. Demanding justice not only to the group, class, or Muslims alone, but includes the entire human being even all beings. $^{18}$

There are many Quranic verses relating to it. One of them is in the form of reprimand to the Prophet Muhammad who almost blamed the Jews for the defense of the family affected by a thief. In this context God says: "And do not become opponents of those who are not guilty (defending) the treacherous." (Q.V. AlNisa'/ 4: 105). Relating to the mandate assigned to the authorities, the community is supposed to respect them and obey their command. However, it should be observed that the obedience to the rulers (uli al-amr) never stands alone but relates to obedience to Allah and His Messenger. In other words, uli al-amr can be followed as long as they fulfill the regulations according to the teachings of Quran. However, if their orders are contrary to the values contained in the teachings of Islam, then it is not justified to obey them. In a popular rule it is explained: "It is not justified for obedience to a creature in disobedience to Khaliq $($ Allah)". It can be seen that Islam teaches obedience is not obedience it self, but conditional obedience. If the conditions are fulfilled then the obedience can be implemented.

\section{Closing}

The process of transformation of society is quite risky if it negates religion. Religion is not going to be a limiting factor, it will provide the moral reference to the change. Western experience which is quite bitter is enough to be good example to us. The arrogance of man in the change by ignoring God finally will give birth to a human catastrophe. The teachings of religion in whatever circumstance will serve as a lamp that will save human life. Human misperception on religion is because of the lack of a comprehensive understanding of the religion. There are also many dominant factors which guide religion to the group interest. It can destroy the sacred function of religion it self. These conditions will bear disappointment and then people will throw the religion away. Religion can

\footnotetext{
${ }^{18}$ M. Quraish Shihab, Wawasan Al-Quran, pp. 425-426.
} 
play important role in the changing society when its values attach in the real life of society.

\section{Refference}

Alexander, David E.dan Rhodes W. Fairbridge, ed. "Thomas Henry Huxley (1825-1895)". Dalam Encyclopedia of Environmental Sciences. Doordreecht: Kluwer Academic Publishers, 1999.

Cox, Harvey. The Secular City: Secularization and Urbanisazion in Theological Perspective. Macmillan, 1966.

Halman, Loek dan Ole Riis, ed. Religion in Secularising Society: The Europen Religion at the End of the 20th Century. Leiden: Brill, 2003.

Hanafi, Hassan. Al-Yami $>n$ wa al-Yasar fi> al-Fikr al-Di>n. Kairo: Madbuli, t.t.

Hidayat, Komaruddin. Wahyu di Langit dan Wahyu di Bumi: Doktrin dan Peradaban Islam di Panggung Sejarah. Jakarta: Paramadina, 2003.

dan Muhammad Wahyuni Nafis. Agama Masa Depan: Perspektif Filsafat Perennial. Jakarta: PT. Gramedia Pustaka Utama, 2003.

Ibnu Taimiyah. Al-Siya>sah al-Syar'iyah. Mesir: Da>r al-Kita>b al-Ara>bi>, 1951.

Iqbal, Muhammad. Tajdi>d al-Fikr al-Di>n. Kairo: Al-Nahdhah, 1963.

Madjid, Nurcholish. Islam Doktrin dan Peradaban: Sebuah Telaah Kritis tentang Masalah Keimanan, Kemanusiaan dan Kemodernan. Cet. Ke-4. Jakarta: Paramadina, 2000.

Maksum, Ali. "Spiritualitas Abad Modern: Reposisi Islam dalam Kancah Kebangkitan Agama". (dikutip dari: http.www.arsip.masjid.telkom.co.id [home page on-line]: Internet (diakses tanggal 14 April 2013 pukul 17.53 WIB).

Naisbitt, John dan Patricia Aburdene. Megatrends 2000: New Directions for Tomorrow. London: Siddwick \& Jackson, 1990.

Nasr, Seyyed. Islam and The Plight of Modern Man. Virginia: ABC International Group, 2000.

Qorib, Muhammad. "Spirit Kosmopolitanisme”. In Harian Republika 19 Desember 2009. 
Schumacher, E.F. A Guide for the Perplexed. Random House, 2011.

Streeten, Paul. Globalisation: Threat and Opportunity. Michigan: Copenhagen Business School Press 2001.

Shihab, Alwi. Islam Inklusif: Menuju Sikap Terbuka dalam Beragama. Bandung: Mizan, 1998.

Shihab, M. Quraish. Wawasan Al-Qur'an: Tafsir Maudhu'i atas Berbagai Persoalan Umat. Bandung: Mizan, 1996.

Tafsir Al-Misbah: Pesan, Kesan dan Keserasian Al-Qur'an, Vol. 1. Jakarta: Lentera Hati, 2006.

---------. Tafsir Al-Misbah: Pesan, Kesan dan Keserasian Al-Qur'an, Vol. 2. Jakarta: Lentera Hati, 2006.

Shiddiqi, Nouruzzaman. Jeram-Jeram Peradaban Islam. Yogyakarta: Pustaka Pelajar, 1996.

Thoyyar, Husni. “Agama dan Pembangunan". (quoted from:

http://huznithoyyar.blogspot.com/ [home page on-line]: Internet (April 15, 2013 time 06.08). 